\title{
Screening for Familial Hypercholesterolemia in 5000 Neonates: A Recall Study
}

\author{
BARBARA L. BLADES, NICHOLAS P. B. DUDMAN, AND DAVID E. L. WILCKEN \\ Department of Cardiovascular Medicine, The University of New South Wales, The Prince Henry Hospital, \\ Sydney, New South Wales, Australia
}

\begin{abstract}
To investigate the feasibility of screening for familial hypercholesterolemia, apolipoprotein B (Apo B) levels were determined in dried blood spot samples on neonatal screening cards from 5000 consecutively born neonates, by radial immunodiffusion assay. The 103 infants with Apo B levels in the top $2 \%$ were recalled for repeat dried blood spot Apo B determinations. Forty-five of the 103 infants were retested, and serum lipid profiles and Apo $B$ levels were determined for both parents of 43 of these infants, and for the mother only for the other two infants. The recalled "top $2 \%$ " group had a higher proportion of females, a higher mean birth weight, a higher mean gestational age and a higher proportion of infants sampled initially on day 5 than in the total screened population, consistent with our previously determined influence of these factors on Apo B levels at screening. The retested group $(n=45)$ was representative of the total recalled group $(n=103)$ with respect to Apo B levels at screening, sex, birth weight, gestational age, and age at sampling for screening. The infants' mean $\pm \mathrm{SD}$ age at retesting was $12.3 \pm 3.3$ months. Their mean Apo B value on retesting was $0.65 \pm 0.20 \mathrm{~g} /$ liter of whole blood (range 0.30 to 1.16 g/liter). Two fathers had had coronary bypass surgery by the age of $\mathbf{4 0}$ and had type II lipid profiles and elevated serum Apo B levels. For both, their child had elevated Apo $B$ levels at recall (both $1.05 \mathrm{~g} /$ liter of whole blood). Another five mothers and five fathers had type II lipid profiles (total and low-density lipoprotein cholesterol more than 95th percentile for their age and sex), and in four of these their child also had elevated Apo B levels at recall $(\geq 0.70$ $\mathrm{g} /$ liter of whole blood). Another eight infants had recall Apo B levels of more than $0.70 \mathrm{~g} /$ liter, of whom two had only had one parent with low-density lipoprotein cholesterol more than the 90 th percentile suggesting genetically determined elevated levels. Despite the arbitrary cutoff point, a total of six of the 45 infants retested had strong indications of having the gene for familial hypercholesterolemia. This gives an estimated frequency of between one in $\mathbf{3 6 5}$ and one in $\mathbf{8 3 0}$ in the total population screened, which is comparable with the reported frequency of one in 500. We conclude that screening for familial hypercholesterolemia using this method is feasible, but that a further study using a cutoff point that takes into account the factors that affect Apo $B$ levels at screening would be useful. (Pediatr Res 23: 500-504, 1988)
\end{abstract}

Received July 29, 1987; accepted January 12, 1988

Correspondence and reprint requests A/Professor D. E. L. Wilcken, Department of Cardiovascular Medicine, Clinical Sciences Building, The Prince Henry Hospital, Little Bay. N.S.W. 2036, Australia.

Supported by the National Heart Foundation, the Ramaciotti Foundation, and Calbiochem-Behring Australia.

\section{Abbreviations}

FH, familial hypercholesterolemia

Apo B, apolipoprotein B

RID, radial immunodiffusion

LDL, low-density lipoprotein

HDL, high-density lipoprotein

HDL-C, HDL cholesterol

VLDL, very low-density lipoprotein

TC, total cholesterol

trigs, triglyceride(s)

$\mathrm{CV}$, coefficient of variation

Atherosclerosis begins to develop in childhood (1), and therefore primary prevention should begin early in life. FH, an autosomal dominantly inherited condition characterized by elevated levels of LDL cholesterol, results in premature atherosclerosis, with myocardial infarction occurring by the 4th or 5th decade of life. The incidence of FH has been estimated at about one in 500 in the general population (2). A neonatal screening programme to detect infants with $\mathrm{FH}$ could identify young at-risk families, and facilitate the early instigation of primary prevention in the infant and the asymptomatic young parents with $\mathrm{FH}$.

The elevated LDL levels found in $\mathrm{FH}$ are secondary to a deficiency of functional cell surface LDL (Apo B,E) receptors resulting from a mutation in the gene coding for this receptor. LDL receptors are largely responsible for the uptake of LDL, and this constitutes the principal mechanism by which LDL is cleared from the blood. Elevated levels of apolipoprotein B (Apo $B$ ), the apoprotein of LDL, provide a good genetic marker for FH (3), and it is possible to measure Apo B in the dried blood spot samples which are routinely collected as part of current neonatal screening programs $(4,5)$. Using a radial immunodiffusion assay which directly measures Apo B in dried blood spot samples (5), we carried out a pilot study to investigate the feasibility of screening for $\mathrm{FH}$ in neonates, by determining Apo B levels for 5000 consecutively born neonates. The analysis of data collected for a 4491 subset of the 5000 neonates screened has been previously presented (6) and shows that the neonate variables of sex, birth weight, gestational age and, to a lesser extent, age at sampling, all influence the neonate's Apo B level at the time of screening, which is usually on days 3 to 5 after birth. In the total population screened, Apo B levels were continuously distributed with no distinct population of infants with abnormally high levels. For recall purposes an arbitrary cutoff point needed to be made. This cutoff point was decided on and the recall commenced before we were aware of the influence of the neonate variables on the Apo B levels at screening.

Although the 95th percentile has usually been used as the 
cutoff point in similar studies where total or LDL cholesterol have been used to screen for hypercholesterolemia or type II hyperlipoproteinemia, in this study the 98th percentile was chosen. This was due to the logistical consideration of a practical size of the work load which would be involved in the recall if this assay was to be routinely implemented within the present N.S.W. Neonatal Screening Program. If too few infants with FH were found within the top $2 \%$, it would not be feasible to screen for FH using this method. Also, for ethical reasons, no "controls" (i.e. infants with Apo B levels below the 98th percentile) were able to be recalled herein. With the cutoff made arbitrarily at the 98th percentile, infants with levels in the top $2 \%$ were recalled and their parents also invited to come in for testing. The recall therefore did not take into account the influence of the neonate variables and was based on the hypothesis that $\mathrm{FH}$ infants would have Apo B levels in the top $2 \%$ for the total neonate population. Herein we report on the results of this recall. The characteristics of the recalled population identified in this way are examined and compared to those of the total screened population. Also, the results obtained for those infants retested and for their parents are examined and compared, and the pick-up rate for the $\mathrm{FH}$ phenotype among both neonates and parents assessed.

\section{SUBJECTS AND SAMPLES}

Apo B levels were determined in dried blood spot samples on newborn screening cards from 5000 consecutively born 3- to 5day-old neonates from three Sydney metropolitan hospitals as previously described (6). As the Apo B values were distributed continuously with no distinct population of infants with abnormally high levels, an arbitrary cutoff point was chosen for recall purposes, which for logistical reasons was placed at the 98th percentile. The 103 neonates with Apo B levels in the top $2 \%$ of the distribution for the total population were recalled for repeat dried blood spot Apo B determinations, and their parents were also invited to come in for testing. Forty-five of the 103 neonates recalled were retested. For 43 of those both parents were also tested and for the other two the mother only was tested. The remaining families either were unable to be contacted or failed to respond to the recall.

Heel-prick blood spot samples were collected onto newborn screening cards from the infants after a 4-h fast. As the establishment of a genetically determined elevated Apo B in the infant depended on a finding of elevated serum Apo B and LDLcholesterol levels in one or both parents, serum samples were collected from the parents after a 12-h fast for total, HDL and LDL cholesterol, total triglycerides, and serum Apo B determinations. Finger-prick dried blood spot samples were also collected from the parents to assess the correlation between levels of Apo $B$ in the dried blood spot samples and in serum to detect possible declines in Apo B antigenicity before assay. Apo B levels, as determined by the method used, have been shown to decrease with increasing temperature of storage and delay before assay $(5$, $6)$.

All samples from parents and infants were collected at the three hospitals taking part in the study. Samples were received in our laboratory within 3 days of sampling. Samples were kept at $4^{\circ} \mathrm{C}$ if there was any delay before transport to our laboratory. On receipt, dried blood spot samples were stored frozen $\left(-16^{\circ}\right.$ C) in sealed plastic bags in an airtight container and assayed within 7 days. Sera were stored at $4^{\circ} \mathrm{C}$ if assayed within a day of receipt or at $-16^{\circ} \mathrm{C}$ and assayed within 7 days.

\section{METHODS}

Assays. Apo B levels in dried blood spot samples on filter paper (neonatal screening cards) were determined using a RID assay as previously described $(5,6)$.
Serum Apo B levels were also determined by RID assay. The immunogel was prepared by pouring $20 \mathrm{ml}$ of $1 \%$ agarose (type A agarose, Calbiochem-Behring, La Jolla, CA) solution in 50 $\mathrm{mM}$ barbital buffer, $\mathrm{pH} 8.8,10 \mu \mathrm{M}$ EDTA, containing $47 \mu \mathrm{l}$ of antiserum to human Apo B, titer $18.2 \mathrm{~g} /$ liter (Behringwerke AG, Marburg, West Germany), onto a level $12 \times 12 \mathrm{~cm}$ glass plate. After setting, the gels were stored in humidiboxes at room temperature until use. Fifty 3-mm diameter wells were cut into the gel just before use. Apo B standard serum (Behringwerke

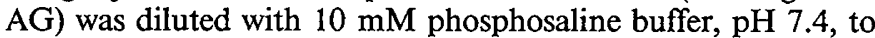
give five standards ranging from 0.10 to $0.80 \mathrm{~g} /$ liter. Control sera and subjects sera were diluted 1 in 3 and 1 in 6 with $10 \mathrm{mM}$ phosphosaline buffer, $\mathrm{pH} 7.4$, immediately before assay. Five- $\mu \mathrm{l}$ aliquots of diluted standard, control, or subjects' sera were pipetted into their appropriate wells in the immunogel, then the gel was incubated at room temperature in a humidibox for 6 days.

The five standards plus a zero standard (phosphosaline buffer only) were assayed in duplicate. The two dilutions of each subject's or control serum were assayed singly. At the end of the incubation time, two diameters perpendicular to each other were measured for each precipitin ring using a Transidyne Calibrating Viewer (Transidyne General Corp., Ann Arbor, MI). The square of the mean diameter of the precipitin ring was used to determine the Apo B concentration of the sample, the Apo B concentrations being a linear function of this value. The Apo B concentration for each control or subject's serum was the average of the Apo B values obtained from the two dilutions after correction for the dilution factor.

Serum TC, total trigs, and HDL-C determinations were carried out by the Department of Clinical Chemistry, The Prince of Wales Hospital, using a Cobas Bio analyser (Hoffman-La Roche, Basel, Switzerland). TC was determined using the Boehringer CHOD-PAP kinetic enzymatic method (Boehringer Mannheim GmbH, Mannheim West Germany). Trigs were determined enzymatically using the Roche triglyceride rapid test (Hoffman-La Roche, Basel, Switzerland). HDL-C was determined using the Boehringer CHOD-PAP method after precipitation of LDLVLDL using PEG 6000 at a final concentration of $100 \mathrm{~g} /$ liter. LDL-cholesterol was estimated using the Friedewald formula (7): LDL-C $(\mathrm{mmol} /$ liter $)=\mathrm{TC}(\mathrm{mmol} / \mathrm{liter})-($ trigs $/ 2.2(\mathrm{mmol})$

$$
\text { liter) + HDL-C) (mmol/liter) }
$$

Quality control of Apo $B$ assays. Herein only one calibrated serum was used for making the blood spot standards. This serum was stored in small aliquots at $-16^{\circ} \mathrm{C}$, and its stability monitored regularly by comparing it to Behring Apo B standard serum by RID assay. Each new batch of blood spot standards and controls was compared with the previous batch to ensure continuity of standard and control values.

Bi-level assayed lipid profile controls (Gilford, Irvine, CA) were used as control sera and for making control blood spots as previously described (6). Control sera and blood spots were stored at $-16^{\circ} \mathrm{C}$. In the serum assay, the between assay $\mathrm{CV}$ for control 1 (mean $\pm \mathrm{SD}=0.73 \pm 0.02 \mathrm{~g} \mathrm{Apo} \mathrm{B} /$ liter) was $2.6 \%$, and for control 2 (mean $\pm \mathrm{SD}=1.28 \pm 0.02 \mathrm{~g} /$ liter) was $1.8 \%$. In the blood spot assay, the between assay CV for control 1 (mean \pm $\mathrm{SD}=0.34 \pm 0.03 \mathrm{~g} /$ liter of whole blood) was $8.2 \%$, and for control 2 (mean $\pm \mathrm{SD}=0.68 \pm 0.07 \mathrm{~g} /$ liter of whole blood) was $10.4 \%$. The mean within assay mean percentage deviation from the mean of duplicates was $2.4 \pm 0.9 \%$ for the serum assay and $4.3 \pm 1.3 \%$ for the blood spot assay.

Good correlation was obtained between the parents' dried blood spot Apo B and serum Apo B $(r=0.865, p<0.0001)$. As the infants' dried blood spot samples were handled in the same way before assay as those of the parents, it was concluded that the infants' samples had not deteriorated and their assayed Apo $B$ levels were good indicators of the infants' serum Apo B levels.

Data analysis. All data analysis was carried out by computer using the UNIX/STATS program $(8,9)$. The results are expressed 
as mean $\pm \mathrm{SD}$ and the significance of the differences between group values were assessed by an unpaired $t$ test.

When neonatal Apo B levels were adjusted to control for the effects of birth weight and sex, the predicted Apo B value for each neonate was calculated using the multiple linear regression equation:

$$
\text { Apo } \mathrm{B}=0.02319 \text { sex }+0.02515 \text { bwt }+0.115984
$$

where Apo B is in $\mathrm{g} /$ liter of whole blood; sex $=1$ if male, 2 if female; bwt = birth weight in $\mathrm{kg}$. The "residual" was calculated by subtracting the predicted value from the actual value. The adjusted Apo $B$ value was obtained by adding the residual to the population mean Apo B (0.234 g/liter of whole blood).

\section{RESULTS}

Comparison of recalled top $2 \%$ with the total screened population. As expected, the mean Apo B level at screening for both males and females in the recalled group was significantly higher than for the same sex in the total population (Table 1).

When the recalled top $2 \%$ and the total population were compared in relation to the proportion of males to females, the mean birth weight, mean gestational age, and proportion of infants initially sampled on days 3,4 , and 5 and after day 5 , significant differences were found. The percentage of females was significantly higher in the recalled group than in the total population; $60 \%$ of the recalled group and $47 \%$ of the total population screened were females $\left(p<0.01\right.$, by one-tailed $\chi^{2}$ test). The mean birth weights of both males and females in the recalled group were significantly higher than for the same sex in the total population, with this difference being more marked in the case of the males (Table 1). Males had higher mean birth weights than females in both the total population and the recalled top $2 \%$, with this difference being more marked in the recalled group, although statistically it was less significant due to a smaller sample size.

The mean gestational ages of both males and females in the recalled group were also significantly higher than for the same sex in the total screened population, and once more this was more marked in the case of the males (Table 1). In the recalled group, no male had a gestational age less than $38 \mathrm{wk}$, whereas the gestational ages of the females ranged down to $34 \mathrm{wk}$.

A significantly higher proportion of the infants in the recalled top $2 \%$ had been sampled on day 5 and lower proportions on days 3 and 4 and after day 5 , than would have been expected from the proportions sampled at each of these times in the total population ( $p<0.005$, one-tailed $\chi^{2}$ test). In the recalled population and in the total population respectively, the percentage of infants sampled on day 3 was 1 and $4 \%$, on day 4,40 and $49 \%$, on day 5,58 and $42 \%$, and after day 5,1 and $5 \%$.

Comparison of the retested group $(n=45)$ with the total recalled top $2 \%(n=103)$. As can be seen from Table 2 , the 45 infants retested were not significantly different from the total

Table 1. Comparison of mean initial Apo B at screening, birth $w t$, and gestational age of recalled top 2\% group with those of total screened population, for both sexes (mean $\pm S D$ )

\begin{tabular}{|c|c|c|c|c|}
\hline & \multicolumn{2}{|c|}{ Males } & \multicolumn{2}{|c|}{ Females } \\
\hline & $\begin{array}{c}\text { Total } \\
\text { population }\end{array}$ & $\begin{array}{l}\text { Recalled } \\
\text { top } 2 \%\end{array}$ & $\begin{array}{c}\text { Total } \\
\text { population }\end{array}$ & $\begin{array}{c}\text { Recalled } \\
\text { top 2\% }\end{array}$ \\
\hline$n$ & 2390 & 41 & 2086 & 62 \\
\hline \multirow{2}{*}{$\begin{array}{l}\text { Initial Apo B } \\
\text { (g/liter of } \\
\text { blood) }\end{array}$} & 0.225 & 0.479 & 0.246 & 0.485 \\
\hline & \pm 0.079 & $\pm 0.053^{*}$ & \pm 0.085 & $\pm 0.080^{*}$ \\
\hline \multirow[t]{2}{*}{ Birth wt (kg) } & 3.39 & 3.69 & 3.29 & 3.45 \\
\hline & \pm 0.59 & $\pm 0.50^{*}$ & \pm 0.56 & $\pm 0.50^{*}$ \\
\hline \multirow{2}{*}{$\begin{array}{l}\text { Gestational age } \\
\text { (wk) }\end{array}$} & 38.95 & 39.70 & 39.15 & 39.67 \\
\hline & \pm 1.94 & $\pm 0.91^{*}$ & \pm 1.88 & $\pm 1.26^{*}$ \\
\hline
\end{tabular}

$* p<0.0001$, different from total population for the same sex $(t$ test).
Table 2. Comparison of mean Apo B at screening, birth wt, and gestational age of those retested from recalled group, with those of total recalled top $2 \%$ (mean $\pm S D)$

\begin{tabular}{|c|c|c|c|c|}
\hline & $n^{\mathrm{A}}$ & $\begin{array}{l}\text { po B at screening } \\
\text { (g/l of blood) }\end{array}$ & $\begin{array}{l}\text { Birth wt } \\
(\mathrm{kg})\end{array}$ & $\begin{array}{l}\text { Gestational age } \\
\text { (weeks) }\end{array}$ \\
\hline \multicolumn{5}{|c|}{ Total recalled top $2 \%$} \\
\hline \multirow[t]{2}{*}{ All } & 103 & 0.482 & 3.548 & 39.68 \\
\hline & & \pm 0.070 & \pm 0.509 & \pm 1.13 \\
\hline \multirow[t]{2}{*}{ Males } & 41 & 0.479 & 3.693 & 39.70 \\
\hline & & \pm 0.053 & \pm 0.495 & \pm 0.91 \\
\hline \multirow[t]{2}{*}{ Females } & 62 & 0.485 & 3.452 & 39.67 \\
\hline & & $\pm 0.080^{*}$ & $\pm 0.499 \dagger$ & \pm 1.26 \\
\hline \multicolumn{5}{|c|}{ Retested group } \\
\hline \multirow[t]{2}{*}{ All } & 45 & 0.485 & 3.545 & 39.64 \\
\hline & & $\pm 0.067 \mathrm{NS} \ddagger$ & $\pm 0.539 \mathrm{NS}$ & $\pm 1.28 \mathrm{NS}$ \\
\hline \multirow[t]{2}{*}{ Males } & 14 & 0.485 & 3.707 & 39.86 \\
\hline & & $\pm 0.060 \mathrm{NS}$ & $\pm 0.590 \mathrm{NS}$ & $\pm 0.95 \mathrm{NS}$ \\
\hline \multirow[t]{2}{*}{ Females } & 31 & 0.485 & 3.472 & 39.55 \\
\hline & & $\pm 0.070 \mathrm{NS}$ & $\pm 0.509 \mathrm{NS}$ & $\pm 1.41 \mathrm{NS}$ \\
\hline
\end{tabular}

${ }^{*} p<0.0001, \dagger p<0.02$, different from males of same group ( $t$ test).

$\ddagger$ NS, not significantly different from the value for the same sex in the total recalled top $2 \%$ ( $t$ test).

recalled top $2 \%$ group with respect to mean Apo B level at initial screening, proportion of males to females, mean birth weight, mean gestational age, and age at initial screening. We concluded therefore that these 45 infants were representative of the total recalled group with respect to these factors.

Retested infants. The mean age of the 45 infants at retesting was $12.3 \pm 3.3$ months, with no significant differences between males and females, their respective mean ages being $12.7 \pm 3.0$ months, $n=14$, and $12.1 \pm 3.4$ months, $n=31$. Their mean dried blood spot Apo B value on retesting was $0.65 \pm 0.20 \mathrm{~g} /$ liter of the whole blood, with values ranging from 0.30 to 1.16 $\mathrm{g} /$ liter. There was no significant difference between the mean Apo B values for males and females $(0.639 \pm 0.179$ and $0.651 \pm$ $0.210 \mathrm{~g} /$ liter of whole blood, respectively), or was there any relationship between the infants' recall Apo B levels and their age at retesting. There was no significant correlation for the group as a whole between the babies' original Apo B levels at screening and their recall Apo B levels, the highest babies at 3-5 days within this top $2 \%$ group not necessarily being the highest babies at $12.1 \pm 3.3$ months. The correlation became more positive, although still did not reach statistical significance, when the infants' original Apo B levels were adjusted to control for the influence of sex and birth weight.

Parents. Forty-five mothers and 43 fathers were tested at mean ages of $30.5 \pm 4.8$ and $32.5 \pm 5.2 \mathrm{yr}$, respectively. When the lipid and Apo B levels in the parents were compared, the fathers had significantly higher serum TC, serum trigs, LDL-cholesterol and serum Apo B, but lower HDL-C than did the mothers (Table 3). The fathers also had higher mean dried blood spot Apo B levels than the mothers although this did not reach statistical significance.

There was a good correlation between the parents' dried blood spot Apo B and serum Apo B levels $(r=0.865, p<0.0001)$ supporting our previous findings (5) that dried blood spot Apo $B$ levels are good indicators of serum Apo B levels. The parents' serum Apo B levels correlated well with their LDL-cholesterol $(r$ $=0.88, p<0.0001)$, their serum TC $(r=0.86, p<0.0001)$ and their serum trigs $(r=0.59, p<0.0001)$. The serum Apo B levels also had a significant negative correlation with their HDL-C levels $(r=-0.36, p=0.0005)$.

The parents' TC and LDL-cholesterol levels were analyzed with reference to their age and sex in relation to the Lipid Research Clinics Reference Values (10) for white men and women as similar information was not available for the Austra- 
Table 3. Comparison of fathers' mean age, and Apo B and serum lipid levels with those of mothers (mean $\pm S D$ )

\begin{tabular}{lcc}
\hline & Mothers & \multicolumn{1}{c}{ Fathers } \\
\hline$n$ & 45 & 43 \\
Age (yr) & $30.5 \pm 4.8$ & $32.5 \pm 5.2$ \\
$\begin{array}{l}\text { Serum Apo B (g/liter of } \\
\quad \text { serum) }\end{array}$ & $1.06 \pm 0.28$ & $1.22 \pm 0.26^{*}$ \\
$\begin{array}{l}\text { Blood spot Apo B (g/li- } \\
\quad \text { ter of whole blood) }\end{array}$ & $0.54 \pm 0.25$ & $0.64 \pm 0.23$ \\
$\begin{array}{l}\text { Total cholesterol } \\
\text { (mmol/liter) }\end{array}$ & $5.06 \pm 0.98$ & $5.50 \pm 0.90 \dagger$ \\
$\begin{array}{l}\text { LDL-cholesterol } \\
\text { (mmol/liter) }\end{array}$ & $3.17 \pm 0.80$ & $3.71 \pm 0.87 \ddagger$ \\
$\begin{array}{l}\text { Trigs (mmol/liter) } \\
\text { HDL-C (mmol/liter) }\end{array}$ & $1.08 \pm 0.55$ & $1.43 \pm 0.84 \S$ \\
\hline
\end{tabular}

${ }^{*} p<0.01, \dagger p<0.05, \ddagger p<0.005, \S p<0.0001$, significantly different from mothers' value $(t$ test).

lian population. Two fathers had already had coronary bypass surgery by the age of 40 . Their total and LDL-cholesterols were elevated, one with both levels above the 95 th percentile and the other, who was known to be adhering to a strict dietary regimen to lower his cholesterol levels, with both levels above the 90 th percentile. Both had serum Apo B levels of more than $1.60 \mathrm{~g} /$ liter. For both fathers, their child had elevated Apo B levels on recall, the level for each being $1.05 \mathrm{~g} /$ liter of whole blood.

Another five mothers and five fathers had type II lipid profiles as defined by having TC and LDL-cholesterol levels above the 95th percentile for their age and sex. For these mothers their mean serum Apo B was $1.59 \pm 0.05 \mathrm{~g} /$ liter and for the fathers it was $1.52 \pm 0.26 \mathrm{~g} /$ liter. In four cases, all with serum Apo B levels of more than $1.50 \mathrm{~g} /$ liter, their child had elevated dried blood spot Apo B levels on recall $(\geq 0.70 \mathrm{~g} /$ liter of whole blood, i.e. equivalent to $\geq 1.20 \mathrm{~g} /$ liter in serum). One more mother was pregnant at the time of testing and had levels above the 95th percentile for both total and LDL-cholesterol and had elevated triglycerides. However, as cholesterol levels can increase by 30 $40 \%$ in pregnancy (11), it was uncertain whether she did have a true type II lipid profile, and so was not classified as such.

Infants with elevated recall Apo B levels. In six cases there were strong indications of the infant having genetically determined elevated Apo B levels ( $\geq 0.70 \mathrm{~g} /$ liter of whole blood), because one of their parents had a type II lipid profile. Another eight infants had recall Apo B levels of more than $0.70 \mathrm{~g} /$ liter. In one case both parents had total and LDL-cholesterol levels above the 90th percentile and in the father's case the LDL-cholesterol was above the 95th percentile. Their serum Apo B levels were 1.33 $\mathrm{g} /$ liter for the mother (aged $24 \mathrm{yr}$ ) and $1.27 \mathrm{~g} /$ liter for the father (aged $25 \mathrm{yr}$ ). This infant therefore also had indications of genetically determined elevated Apo B levels. In another case, an infant with the highest recall Apo B value (1.16 g/liter of whole blood), the father (aged $26 \mathrm{yr}$ ) had LDL-cholesterol levels of more than the 90th percentile and a serum Apo B of $1.24 \mathrm{~g} /$ liter, possibly indicating inherited elevated levels. In another case, the father had elevated trigs $(4.1 \mathrm{mmol} / \mathrm{liter})$ and raised serum Apo $B$ levels ( $1.40 \mathrm{~g} /$ liter). In the remaining five cases, neither parent had elevated ( $>90$ th percentile) total or LDL-cholesterol and their serum Apo B levels were all $<1.20 \mathrm{~g} /$ liter for mothers and $<1.30 \mathrm{~g} /$ liter for fathers.

Correlations between parents' lipid and Apo $B$ levels and babies' original and recall Apo $B$ levels. Within this group of infants with Apo B values in the top $2 \%$ at initial screening, there was no correlation between either the mothers' or the fathers' lipid and Apo B levels and the infants' original Apo B level. When the infants' original Apo B levels were adjusted to control for the influence of sex and birth weight, all correlations with parents' lipid or Apo B levels became more positive, but were still not significant.
There were significant correlations between the infants' recall Apo B and both the mothers' and the fathers' blood spot Apo B ( $r=0.40$ and 0.47 , respectively, both $p<0.01$ ), and with the mothers' $(r=0.33, p<0.05)$ but not the fathers' serum Apo B. For the mothers, there was also a significant although not strong, correlation with their total cholesterol $(r=0.30, p<0.05)$. There was no correlation between the fathers' total, LDL-, or HDL-C or trigs levels and the infants' recall Apo B levels. However, infants whose parents had total or LDL-cholesterol levels in the top $10 \%$ for their age and sex, tended to have higher recall Apo B levels than those with parents whose levels were below the 90th percentile, although the differences did not reach statistical significance.

Pick-up rate for cases of $F H$ phenotype in the population screened. In six of the 45 infants retested, their persisting elevated Apo B levels appeared to be genetically determined as one of their parents had a type II lipid profile. Although the distribution of neonate variables suggested that the retested group was a true random sample of the recalled group, bias in those parents responding to the recall cannot be excluded. Therefore the estimated pick-up rate in the total population screened $(n=5000)$ was between at least one in 830 (if the 45 were not a true random sample of the total recalled top $2 \%$ ) to at the most one in 365 (if the retested infants were a true random sample of the recalled infants). The pick-up rate for parents was similar with 12 of the 88 tested having a type II lipid profile.

\section{DISCUSSION}

The frequency of FH in Australia has not yet been determined; however, no "founder effect" in relation to $\mathrm{FH}$ has been reported in this country, and the population in this study was quite heterogeneous. For these reasons it is likely that the frequency of $\mathrm{FH}$ in this population is about one in 500, which is the estimated frequency in the United States (2). By recalling infants with Apo B levels in the top $2 \%$ (i.e. one in 50 ) of the distribution of values for the population screened, we had expected that if all the infants with $\mathrm{FH}$ were in this group, that about $90 \%$ of the recalled group would be "normal" on retesting. By not taking into account those factors found to influence Apo B levels at the time of testing (6), the proportion of "normals" could be expected to be higher than originally predicted; and a number of infants with FH, particularly males of low birth weight and gestational age, and who could have been sampled on a day other than day 5 , may not have been recalled and would not have been identified.

The large percentage of "normals" expected within the recalled group and the now known influence of the neonate variables on Apo B at screening at least partly explain the lack of correlation between the neonates' Apo B levels at screening and their recall Apo B, and with the parents' lipid and Apo B levels. When the infants' original Apo B levels were adjusted to control for the influence of sex and birth weight, all correlations became more positive, indicating that many infants with initially elevated Apo $B$ levels were actually normolipidemic but were female and/or had a high birth weight.

Despite the inadequacies of the chosen cutoff point, six of the 45 infants retested had strong indications of having $\mathrm{FH}$. Another three infants also had indications of genetically determined elevated Apo B levels (one possibly being hyperapo- $\beta$-lipoproteinemic and the father having normal cholesterol levels but elevated trigs and Apo B levels). There were five more infants with persisting elevated Apo B levels but with both parents normolipidemic with normal Apo B levels. Whether their levels on recall were elevated due to diet, inadequate fasting, polygenic factors, mutation, or nonpaternity could not be determined within the scope of this study.

This study detected six infants with a persistent elevation of Apo B and one parent with a FH phenotype. These were identified from the 45 infants retested from the 103 recalled. 
Because there was only a $44 \%$ response to the recall, and because babies of responders and nonresponders were comparable for the neonate variables examined, it is likely that this technique could have identified 13 of 14 babies with the $\mathrm{FH}$ phenotype, giving an incidence of one in 365 in the total population. This is of the same order as the estimated frequency of $\mathrm{FH}$ in the United States of about one in 500. Even without having retested infants with Apo B levels at screening below the 98th percentile, it could be concluded that the simplistic approach used for this recall has most probably resulted in a number of infants with $\mathrm{FH}$ being classified as normal at screening. By taking into account at least the neonate's sex and birth weight when classifying their results as "normal" or "abnormally high," a higher pick-up rate should result (6).

A study would be valuable with a cutoff point placed minimally at the 95th percentile after controlling for at least these variables. Also the rate of false-negatives could be estimated by recall of a subset of infants with levels below the cutoff point. As a type II phenotype in both parent and infant could be due to polygenic inheritance or common environmental factors, rather than a FH genotype, a confirmatory test for the FH genotype should be carried out on all subjects with a type II phenotype. $\mathrm{FH}$ is defined by a lack of functional cell surface Apo B,E receptors, so an assay to quantitate Apo B,E receptor activity in either skin fibroblasts (12) or peripheral blood lymphocytes (1316) could be the confirmatory test. The true pick-up rate for $\mathrm{FH}$ using this screening technique could then be determined.

Acknowledgements. The authors thank the Pathology Departments of the Royal Hospital for Women, Paddington, The St. George Hospital, Kogarah, and The Sutherland Hospital, Caringbah, for the collection of samples, and the pediatricians and obstetrician of these hospitals who assisted in contacting the families involved in the recall. We are grateful to our hospital Department of Clinical Chemistry for carrying out the cholesterol and triglyceride determinations. We acknowledge the cooperation of the Oliver Latham Laboratory, The Macquarie Hospital, North Ryde, and in particular Dr. Bridget Wilcken.

\section{REFERENCES}

1. Newman WP, Freedman DS, Voors AW, Gard PD, Srinivasan SR, Cresanta JL, Williamson GD, Webber LS, Berenson GS 1986 Relation of serum lipoprotein levels and systolic blood pressure to early atherosclerosis. The Bogalusa Heart Study. N Engl J Med 314:138-144

2. Goldstein JL, Brown MS 1983 Familial hypercholesterolemia. In: JB Stanbury, JB Wyngaarden, DS Fredrickson, JL Goldstein, MS Brown (eds) The Metabolic Basis of Inherited Disease, 5th ed. McGraw Hill, New York, pp 672712

3. Avogaro P, Bon GB, Cazzolato G, Quincy GB 1979 Are apolipoproteins better discriminators than lipids for atherosclerosis. Lancet 1:901-903

4. Van Biervliet JP, Vinaimont N, Caster H, Rosseneu M, Belpaire F 1982 A screening procedure for dyslipoproteinemia in the newborn. Apoprotein quantitation on dried blood spots. Clin Chim Acta 120:191-200

5. Dudman NPD, Blades BL, Wilcken DEL, Aitken JM 1985 Radial immunodiffusion assay of apolipoprotein $B$ in blood dried on filter paper-a potential screening method for familial type II hypercholesterolaemia. Clin Chim Acta 149:117-127

6. Blades BL, Dudman NPB, Wilcken DEL 1987 Variables affecting apolipoprotein B measurements in 3- to 5-day-old babies; a study of 4491 neonates. Pediatr Res 21:608-614

7. Friedewald WT, Levy RI, Fredrickson DS 1972 Estimation of plasma low density lipoprotein cholesterol concentration without use of the preparative ultracentrifuge. Clin Chem 18:449-502

8. Perlman G 1980 Data analysis programs for the UNIX operating system. Behav Res Methods Instrum 12:554-558

9. Perlman G 1982 UNIX/STAT: Compact data analysis programs for UNIX. In: Proceedings of the 1982 Summer USENIX Conference USENIX, Boston

10. Rifkind BM, Segal P 1983 Lipid Research Clinics Program reference values for hyperlipidemia and hypolipidemia. JAMA 250:1869-1872

11. Glueck CJ, Christopher C, Tsang RC, Mellies MJ 1980 Cholesterol-free diet and the physiologic hyperlipidemia of pregnancy in familial hypercholesterolemia. Metabolism 29:949-955

12. Goldstein JL, Brown MS 1974 Binding and degradation of low density lipoprotein by cultured human fibroblasts. J Biol Chem 249:5153-5162

13. Ho YK, Brown MS, Kayden HJ, Goldstein JL 1976 Binding, internalization, and hydrolysis of low density lipoprotein in long-term lymphoid cell lines from a normal subject and a patient with homozygous familial hypercholesterolemia. J Exp Med 144:444-455

14. Andersen GE, Johansen KB 1980 LDL receptor studies in children with heterozygous familial hypercholesterolemia $(\mathrm{FH})$ : measurement of sterol synthesis in blood lymphocytes. Acta Paediatr Scand 69:447-452

15. Mistry P, Miller NE, Laker M, Hazzard WR, Lewis B 1981 Individual variation in the effects of dietary cholesterol on plasma lipoproteins and cellular cholesterol homeostasis in man. J Clin Invest 67:493-502

16. Cuthbert JA, East CA, Bilheimer DW, E Lipsky P 1986 Detection of familial hypercholesterolemia by assaying functional low-density-lipoprotein receptors on lymphocytes. N Engl J Med 314:879-883 